\title{
ZANESLJIVOST VOLUMENSKIH FUNKCIJ NA PRIMERU DREVESNE VRSTE SMREKE V SLOVENIJI
}

\section{THE RELIABILITY OF VOLUME FUNCTIONS BASED ON SPRUCE TREE SPECIES IN SLOVENIA}

\author{
Gal KUŠAR ${ }^{1}$, David HLADNIK², Milan HOČEVAR ${ }^{3}$ \\ (1) zasebni raziskovalec, Kavškova ulica 7, SI-1000 Ljubljana, Slovenija. gal.kusar@guest.arnes.si \\ (2) BF Oddelek za gozdarstvo in obnovljive gozdne vire, Večna pot 83, SI-1000 Ljubljana, Slovenija, david.hladnik@bf.uni-lj.si \\ (3) Spodnje Pirniče 77 B, SI-1215 Medvode, Slovenija, milan.hocevar@guest.arnes.si
}

\begin{abstract}
IZVLEČEK
Primerjali smo različne volumenske funkcije za ocenjevanje volumnov dreves. S pomočjo sekcijskih meritev (Newtonova metoda) smo izračunali prave ocene volumnov dreves 88 posekanih smrek na Pokljuki. Te smo uporabili za izdelavo regionalnih trovhodnih volumenskih funkcij, (dvovhodnih) deblovnic in tarif. Standardna napaka ocene povprečne vrednosti volumna drevesa je najmanjša pri trovhodnih volumenskih funkcijah $(5,0 \%)$, nato pri deblovnicah $(11,7 \%)$ in največja pri tarifah $(15,1$ \%). Zanesljivost in uporabnost izdelanih regionalnih ter drugih volumenskih funkcij smo preverili na dveh hektarskih raziskovalnih ploskvah. Ugotovili smo, da s prirejenimi nemškimi deblovnicami smrekam določimo previsoke volumne. Ker volumne iz teh deblovnic uporabljamo tudi pri določanju prirejenih tarif na Slovenskem, je s takim postopkom določen tarifni razred z vsaj za $5 \%$ previsokimi volumni dreves.
\end{abstract}

Ključne besede: volumenske funkcije, volumen dreves, lesna zaloga, smreka (Picea abies), Pokljuka

\begin{abstract}
Various volume functions used for tree volume estimations were compared by the authors. Using section measurements (Newton's method), they calculated the real tree volumes of 88 felled spruce trees on the Pokljuka plateau. The real tree volumes were used to form regional three-entry volume functions, (two-entry) volume tables, and tariff functions. The standard error of the average tree volume estimation is the lowest for three-entry volume functions (5.0\%), then for volume tables (11.7\%), and the highest for tariffs (15.1\%). The reliability and applicability of the developed regional and other volume functions was verified on two one-hectare research plots. It was established that by applying the adapted German volume tables, the measured spruce volumes were too high. As the volumes measured in this manner are used when determining the adapted tariffs in Slovenia, this procedure results in a tariff class of at least $5 \%$ too high tree volumes.
\end{abstract}

Key words: volume functions, tree volume, growing stock, spruce (Picea abies), Pokljuka plateau

GDK 524:174.7Picea abies(045)=163.6

Prispelo / Received: 08. 07. 2013

Sprejeto / Accepted: 20.12. 2013

\section{UVOD}

\section{INTRODUCTION}

Namen prispevka je oceniti zanesljivost volumenskih funkcij za smreko in preveriti, kakšna je zanesljivost pri določanju tarif $\mathrm{v}$ enomernih gozdnih sestojih. Volumenske funkcije, ki jih uporabljamo za izračune volumna dreves in lesne zaloge, so različno točne in natančne. Pri izračunu volumna dreves namreč vključujejo različno število neodvisnih spremenljivk (prsni premer, višina drevesa, dodatni premer), kar vpliva na njihovo zanesljivost in uporabnost. Prav tako je namen prispevka na primeru smreke prikazati prednosti in pomanjkljivosti različnih volumenskih funkcij, ki jih uporabljamo v Sloveniji.
Za ugotavljanje volumna dreves ( $V$ ) lahko uporabljamo štiri (Wagner, 1982; Hočevar, 1995) osnovne tipe volumenskih funkcij, ki se med seboj razlikujejo glede na vhodne podatke - neodvisne spremenljivke: prsni premer drevesa $(D)$, višina drevesa $(H)$, zgornji premer drevesa $(D Z)$ in dodatni zgornji premer $(D Z G)$, ki se upoštevajo pri izračunu:

- štirivhodne volumenske funkcije;

$V=\mathrm{f}(D, H, D Z, D Z G)$

- trovhodne volumenske funkcije; $V=\mathrm{f}(D, H, D Z)$

- dvovhodne volumenske funkcije - deblovnice; $V=\mathrm{f}(D, H)$

- enovhodne volumenske funkcije - tarife; $V=\mathrm{f}(D)$ 
Za konstruiranje volumenskih funkcij bi lahko uporabili še večje število meritev dodatnih zgornjih premerov, vendar merjenje dodatnih znakov na (stoječem) drevesu zahteva večjo porabo časa in večje stroške. Cilj konstruiranja večvhodnih volumenskih funkcij je z dodatnimi meritvami zgornjega premera povečati natančnost ocenjevanja volumna, hkrati pa tako oceno zagotoviti z ne prevelikim številom spremenljivk. Van Laar in Akça (2010) sta med najbolj pogosto uporabljenimi spremenljivkami v volumenskih funkcijah poleg prsnega premera in višine drevesa navedla še premer drevesa na višini začetka živih vej krošnje, premer na treh desetinah drevesne višine, premer na $7 \mathrm{~m}$ višine, višine na dveh tretjinah, polovici ali treh četrtinah vrednosti prsnega premera. Pri praktičnem delu so se v gozdnih inventurah uveljavili zlasti dodatni premeri na treh desetinah drevesne višine ter na 6 ali 7 metrih višine (Tomppo in sod., 2010).

Trovhodne volumenske funkcije so zanesljive na regionalnih ravneh, ker trije vhodni podatki pojasnjujejo tudi del razlik v obliki debla dreves, na katere vplivajo rastiščne razmere in različni načini gospodarjenja. Napaka ocene pri dvovhodnih volumenskih funkcijah - deblovnicah - se lahko zmanjša, če so funkcije določene/uporabljene za homogena območja (Schmidt in sod., 1971). Najmanj zanesljive pa so tarife, ki so dovolj zanesljive le za oceno lesne zaloge v izbranem sestoju, za oceno volumna posameznega drevesa pa je napaka zaradi individualnih odstopanj za posamezno drevo prevelika (Kušar, 2007). Večvhodne volumenske funkcije so bolj zanesljive, zahtevajo pa več meritev, dražje inštrumente ter bolj šolane in izkušene merilce in so zato stroškovno ter časovno manj primerne. V praksi lahko najbolj enostavno in natančno izmerimo prsni premer $(D)$, težje in manj natančno višino drevesa $(H)$, še težje pa izmerimo obliko drevesa oz. zgornji premer $(D Z)$. Zato so za praktično uporabo najenostavnejše tarife, nato deblovnice in nazadnje trovhodne volumenske funkcije.

Trovhodne volumenske funkcije navadno kot vhodne podatke uporabljajo prsni premer $(D)$, višino drevesa $(H)$ in zgornji premer $(D Z)$, ki je lahko izmerjen relativno na tretjini $(D 0,3)$ ali polovici $(D 0,5)$ drevesne višine ali pa absolutno na 7 metrih drevesne višine (D7). Merjenje zgornjega premera na relativni višini je zahtevnejše in zamudnejše kot merjenje na absolutni višini. Volumenske funkcije, ki upoštevajo zgornji premer, izmerjen na relativni višini, so zanesljivejše, saj upoštevanje zgornjega premera na absolutni višini lahko povzroči sistematične napake pri zelo nizkih ali zelo visokih drevesih (Winzeler, 1986). Pri trovhodnih volumenskih funkcijah v Švici upoštevajo kot vhodne podatke prsni premer $(D)$, višino drevesa $(H)$ in zgornji premer na 7 m (D7), ki v volumenski enačbi dobro pojasni razlike $v$ obliki debla. Švicarji so trovhodne volumenske funkcije za posamezne drevesne vrste izdelali na podlagi sekcijskih meritev. Zanesljivost so ocenjevali s povprečno napako odstopanj volumnov posameznih dreves (AR - average residual) in standardnim odklonom odstopanj (SR - standard deviation of the residuals) v odstotkih od povprečne referenčne vrednosti. Povprečna napaka odstopanj (AR) znaša po posameznih debelinskih stopnjah za smreko od -0,3 do 0,9\%, standardni odklon (SR) pa od 3,61 do 5,08\% pri $R^{2}$ je 0,997 (Kaufmann, 2001; Lanz, 2004). Prednost trovhodnih volumenskih funkcij je v tem, da so zanesljive na širših območjih, saj se z meritvijo in uporabo višine dreves $(H)$ ter zgornjega premera $(D Z)$ bistveno izboljša zanesljivost določitev volumna posameznega drevesa. Znano je, da meritev dodatnega premera pojasni velik delež variance volumna individualnih dreves (Kaufmann, 2001). Te razlike so lahko posledica različnih rastiščnih dejavnikov ali pa tudi individualne raznolikosti dreves.

Deblovnice (npr. nemške) navadno kot vhodna podatka uporabljajo prsni premer $(D)$ in višino drevesa $(H)$. So manj zanesljive kot trovhodne volumenske funkcije in za posamezne drevesne vrste veljajo na natančno določenih regionalnih območjih. Pri njihovi uporabi ni potrebno zamudno merjenje zgornjega premera. Za smreko so nemške deblovnice izdelali na podlagi sekcijskih meritev več tisoč dreves v enodobnih sestojih po vsej Nemčiji (Bauer, 1890, cit. po Čokl, 1962). Pri izdelavi teh deblovnic so najprej iz ocen pravih volumnov dreves (sekcijske meritve) izračunali povprečna oblikovna števila, jih nato grafično izravnali ter iz tako izravnanih oblikovnih števil izračunali volumne dreves po premerih in višinah (Čokl, 1962). Ker deblovnice navadno veljajo le za ožja območja, za katera so izdelane, je lahko vprašljiva uporabnost nemških deblovnic v slovenski gozdarski praksi. Zato je Čokl (1962) izdelal tudi regionalne deblovnice za smreko v celjskem okraju. Izdelane so bile na podlagi sekcijskih meritev 789 dreves in veljajo v razponu od 10 do $70 \mathrm{~cm}$. Pri konstruiranju volumenskih funkciji s povečanjem števila modelnih dreves njihova natančnost sprva močno narašča, pozneje pa porast natančnosti vse bolj pojema. Tako naj bi za izdelavo zanesljivih dvovhodnih deblovnic zadostovale meritve okoli 200 modelnih dreves (SchmittSchneider, 1959, cit. po Čokl, 1962). Seveda pa morajo drevesa dobro predstavljati sestoj in biti naključno ali sistematično izbrana. Kljub temu, da odsevajo rastiščne razmere na celjskem, je Čokl (1962) ugotovil, da bi te tablice za slovenske razmere lahko bile boljše od nem- 
ških. Vendar je v slovenski gozdarski praksi ostala uporaba nemških deblovnic, predvsem za izbiranje ustreznih prilagojenih enotnih francoskih tarif.

Pri enovhodnih volumenskih funkcijah ali tarifah (npr. prilagojenih enotnih francoskih tarifah) kot neodvisna spremenljivka nastopa le še prsni premer (D). Večina evropskih držav kljub manjši zanesljivosti uporablja tarife za določanje volumna dreves in izračun lesne zaloge (Tomppo in sod., 2010). Vendar tarife določajo na podlagi volumenskih funkcij oziroma jih kalibrirajo na podlagi dreves iz podvzorca, npr. v Švici (Kaufmann, 2000; 2001). Ker na Slovenskem takih metod še ne uporabljamo, smo v prispevku preverili, ali je primerno, da tarife določamo na podlagi referenčnih vrednosti iz nemških dvovhodnih deblovnic, ki so v tabelarični ali v prilagojeni polinomski obliki (Puhek, 2003). V domačih raziskavah, npr. Kotar (1970) in Rebula (2002), so bile namreč nemške deblovnice izbrane kot referenca za oceno pravega volumna debeljadi. Bilo pa je večkrat opozorjeno, da ne dajejo dobrih referenčnih vrednosti Čokl (1962), še zlasti ne za jelko na Slovenskem (Rebula, 1995; 1996).

V članku o jelki (Hladnik in Kobal, 2013) pa smo celo pokazali, kako so bile pri nas neprimerno predelane. Iz povprečnih oblikovnih višin za posamezne starostne razrede so bili za vsako drevesno vrsto izračunani še novi povprečni volumni za eno samo deblovnico. Povprečne vrednosti za vsak premer in višino dreves so bile izračunane s tehtanjem podatkov oziroma upoštevanjem števila modelnih dreves v izvornih deblovnicah, izdelanih v različnih regijah in za različne starostne razrede.

\section{METODE DELA}

\section{METHODS}

Na podlagi sekcijskih meritev smrek smo izračunali prave volumne dreves in izdelali trovhodne volumenske funkcije, deblovnice in tarife. Izdelane funkcije smo preizkusili na dveh raziskovalnih ploskvah na Pokljuki.

Podatki o 88 smrekah, ki smo jih uporabili v tem prispevku za izdelavo volumenskih funkcij, izvirajo iz raziskave o zanesljivosti ugotavljanja volumna dreves in lesne zalogo (Kušar, 2007). Sekcijske meritve podrtih dreves $\left(\mathrm{N}_{\text {ploskev }}=7, \mathrm{~N}_{\text {dreves }}=88\right)$ smo opravili na izbranih raziskovalnih objektih (začasnih krožnih vzorčnih ploskvah) v GGE Pokljuka leta 2004. Vzorčne ploskve velikosti 0,28 ha (premer $30 \mathrm{~m}$ ) smo postavili v sestojih, kjer so bila že odkazana drevesa za posek. Gre za enodobne, enovrstne (smrekove) sestoje, $\mathrm{v}$ razvojnih fazah drogovnjaka $\left(\mathrm{N}_{\text {ploskev }}=3, \mathrm{~N}_{\text {dreves }}=61\right)$ in debeljaka $\left(\mathrm{N}_{\text {ploskev }}=4, \mathrm{~N}_{\text {dreves }}=\right.$ 27), na nadmorskih višinah med 1200 in 1300 metrih. Za konstruiranje volumenskih funkcij smo uporabili meritve normalnih, nepoškodovanih in enovrhatih dreves.
Posekano drevo smo razdelili na dvometrske sekcije in na sredini vsake izmerili navzkrižna premera, saj obsega ni bilo mogoče izmeriti, ker so drevesa ležala na tleh. Za zadnjo popolno sekcijo, ko premer naslednje sekcije pade pod $7 \mathrm{~cm}$, smo izmerili tudi premer na koncu te sekcije ( $1 \mathrm{~m}$ od sredine sekcije) ter dolžino zadnje sekcije (vrh) od konca zadnje popolne sekcije do vrha drevesa. Premere smo merili s premerko, na mm natančno. Pri prežaganih drevesih smo pri dolžini sekcije upoštevali, da so zaradi širine reza žage debla krajša za $1 \mathrm{~cm}$ za vsak rez žage. Z meritvami smo tako dobili premere drevesa na dolžinah $1 \mathrm{~m}, 3 \mathrm{~m}, 5 \mathrm{~m}, 7 \mathrm{~m}$ ... Dodatno pa smo izmerili še premer na panju $(0,3 \mathrm{~m})$ in že na stoječem drevesu tudi na prsni višini $(1,3 \mathrm{~m})$. V snemalni list smo dodali še naslednje podatke: starost drevesa, premere po sekcijah, dolžino zadnje sekcije do vrha in skupno dolžino drevesa (Kušar, 2007). Za oceno pravega premera sekcije smo vzeli aritmetično sredino obeh navzkrižnih meritev (odstopanja meritev v obeh smereh so bila minimalna), zaokroženo navzdol na cel $\mathrm{mm}$. Celotni volumen debla $\left(v_{n}\right)$ smo dobili s seštevanjem volumnov posameznih sekcij, ki smo jih izračunali po standardnih obrazcih za Newtonovo sekcijsko metodo (Hočevar, 1995; Husch in sod., 2003). Volumen prve sekcije od 0 do $0,3 \mathrm{~m}$ smo izračunali po formuli za volumen valja, s premerom, izmerjenim na $0,3 \mathrm{~m}$ (majhno sistematično podcenjevanje volumna prve sekcije). Valj so za oceno volumna panja predlagali že Husch in sod. (2003). Zapisali so, da je valj primeren in običajno uporabljen za oceno volumna, čeprav je deblo proti panju podobno neiloidu. Zapisali so tudi (Husch in sod., 2003), da volumne sekcij računamo po Huberjevem, Smalianovem in Newtonovem obrazcu. Če sekcije niso daljše od 1 metra, je primeren tudi Smalianov obrazec, drugače pa sta natančnejša Huberjev in Newtonov obrazec. V spodnjem delu debla, ki je zaradi koreničnika razširjen in podoben neiloidu, so odsvetovali Newtonov obrazec. Volumen druge sekcije od 0,3 do 1,0 m smo izračunali po formuli za prisekan paraboloid. Volumne nadaljnjih sekcij smo izračunali po Newtonovi formuli tako, da je bila dolžina ene sekcije 4 m (združeni dve dvometrski osnovni sekciji, da smo dobili premere na začetku, sredi in na koncu sekcije). Tako je bila tretja sekcija pri drevesu od 1 do 5 metra, četrta od 5 do 9 m. Če je pred vrhom ostala še kakšna 2-metrska sekcija ali nepopolna 1- metrska, smo njen volumen določili po formuli za prisekan paraboloid. Volumen zadnje sekcije (vrha) smo izračunali po formuli za stožec. V primeru debelejših vej (nad $7 \mathrm{~cm}$ ) smo prišteli k volumnu debla še volumen vej. Kot volumen drevesa smo torej upoštevali volumen debeljadi, ki jo sestavljajo: panj, deblo, vrh in debelejše veje (Kušar, 2007). 
Na podlagi ocen pravih volumnov dreves $\left(v_{n}\right)$, izračunanih s sekcijskimi meritvami po Newtonovem obrazcu, smo z multiplo (za trovhodne volumenske funkcije, deblovnice) in polinomsko regresijsko analizo (tarife), za Pokljuko izdelali regionalne trovhodne volumenske funkcije, deblovnice in tarife (Kušar, 2007, preglednica 1). Pri izdelavi regionalnih dvovhodnih deblovnic smo upoštevali enake kombinacije spremenljivk ( $d$ in $h$ ), kot jih upoštevajo različne evropske dvovhodne deblovnice (Zianis in sod., 2005). Nato smo na vzorcu sekcijskih dreves primerjali zanesljivost različnih volumenskih funkcij (trovhodnih volumenskih funkcij, deblovnic in tarif, preglednica 1).

Standardna napaka ocene povprečne vrednosti volumna drevesa, izračunanega z regionalnimi volumenskimi funkcijami (Kušar, 2007), ki smo jih izdelali s pomočjo sekcijskih meritev, je najmanjša pri trovhodnih volumenskih funkcijah (5,0 \%), nato pri deblovnicah $(11,7 \%)$ in največja pri tarifah (15,1\%). Modele konstruiranih regionalnih volumenskih funkcij (Kušar, 2007) smo presojali tudi po deležih pojasnjene variabilnosti. Delež variabilnosti odvisne spremenljivke $v_{n^{\prime}}$ ki ga pojasnimo z regresijo med odvisno spremenljivko $v_{n}$ in neodvisnimi spremenljivkami $\left(d, h\right.$ in $\left.d_{7}\right)$, je zelo velik. Že vključitev samo ene spremenljivke $(d)$ v model pojasni velik del variabilnosti $\left(\mathrm{R}^{2}\right.$ je 0,9766$)$. Pri deblovnicah, z vključitvijo še ene spremenljivke $(h)$, je $R^{2}$ 0,9865. Pri trovhodnih volumenskih funkcijah, $z$ vključitvijo še ene dodatne spremenljivke $\left(d_{7}\right)$, pa se še poveča delež pojasnjene variabilnosti $\left(R^{2}\right.$ je 0,9976$)$.

Konstruirane regionalne volumenske funkcije $\mathrm{Ku}-$ šar, 2007) smo najprej primerjali z drugimi volumenskimi funkcijami iz preglednice 1. Švicarske trovhodne volumenske funkcije (Hoffmann, 1984, cit. po Kaufmann, 2001) dajo volumen debeljadi s skorjo (panj, deblo $\mathrm{z}$ vrhom), kot vhodne podatke pa zahtevajo pr-

Preglednica 1: Testirane enačbe volumenskih funkcij (v volumen drevesa, $d$ - prsni premer, $d_{7}$ - premer drevesa na višini 7 metrov, h - višina drevesa) sni premer $(D)$, višino drevesa $(H)$ in zgornji premer drevesa na sedmih metrih (D7). Nemške dvovhodne deblovnice (Puhek, 2003) dajo volumen debeljadi (deblo in veje, debelejše od $7 \mathrm{~cm}$ ), kot vhodna podatka pa zahtevajo prsni premer $(D)$ in višino drevesa $(H)$. Prilagojene enotne francoske (PEF) tarife (Čokl, 1956; 1957; 1959; 1980; Kotar, 2003) dajo prav tako volumen debeljadi (deblo in veje, debelejše od $7 \mathrm{~cm}$ ), kot vhodni podatek pa zahtevajo prsni premer $(D)$ drevesa. Razdeljene so na tri vrste glede na zgradbo sestoja.

Volumenske funkcije, deblovnice in tarife smo preizkusili na dveh hektarskih raziskovalnih ploskvah, ki sta bili že predstavljeni v sklopu preučevanja smrekovih gozdov na Pokljuki (Hladnik in Skvarča, 2009). Ploskvi sta uvrščeni v smrekovja mrazišč na nadmorskih višinah $1190 \mathrm{~m}$ (ploskev 49) in $1270 \mathrm{~m}$ (ploskev 39). Izbrali smo ju, ker ležita v sestojih starejših debeljakov, $\mathrm{v}$ katerih poteka počasna obnova in sta pred končnim posekom primerni za ponazoritev razlik med različnimi modeli, s katerimi določamo lesno zalogo v gozdnih sestojih. Drevesa na raziskovalnih ploskvah so bila nazadnje izmerjena leta 2009, ko smo ob merjenju prsnih premerov z merskim trakom izmerili tudi premere $\mathrm{s}$ finsko premerko na višini $7 \mathrm{~m}$ in njihovo višino (slika 1, preglednica 2).

V enomernih sestojih, ki jih zaradi dolgih pomladitvenih dob ni mogoče uvrstiti med enodobne, je bila ocenjena starost dreves 185 let na ploskvi 39 in 140 let na ploskvi 49. Na podlagi modelnih dreves je bilo ocenjeno, da so sestoji nastali z dolgotrajno, do 40-letno pomladitveno dobo (Čokl, 1971), kar je bilo potrjeno tudi ob zadnjih meritvah, ko smo o razlikah v starosti sklepali na podlagi štetja branik na panjih posekanih smrek (Hladnik in Skvarča, 2009). Posebej nismo ocenjevali razlik $\mathrm{v}$ rasti dreves in dolžine obdobja zastrtosti, ocenjevali smo le razlike $\mathrm{v}$ starosti. Na podlagi

Table 1: Comparison of tested volume equations ( $\mathrm{v}$ - volume of the tree, $d$ - diameter at breast height, $d_{7}$ - stem diameter at $7 \mathrm{~m}$ above the base of the tree, $\mathrm{h}$ - height of the tree)

\begin{tabular}{|c|c|c|}
\hline Vrsta & Oznaka & Enačbe \\
\hline \multirow{2}{*}{ trovhodne vol. funkcije } & Kušar, 2007 & $\begin{array}{l}v=0,220267+0,0000638938 \cdot d_{7}^{2} \cdot h+0,000503564 \cdot d^{2}+0,000145427 \cdot d_{7}^{2}-0,0000185899 \cdot d_{7}^{3} \\
-0,00821086 \cdot h-0,0118515 \cdot d-1,93361 \mathrm{e}-8 \cdot d^{3} \cdot h+2,05352 \mathrm{e}-7 \cdot h^{4}-2,4807 \mathrm{e}-7 \cdot d \cdot h^{3}\end{array}$ \\
\hline & $\begin{array}{l}\text { Hoffmann, 1984, } \\
\text { cit. po Kaufmann, } 2001\end{array}$ & $v=0,029504+0,46756^{*} d_{7}^{2} \cdot h+2,43885^{*} d^{2}-5,74664^{*} d_{7}^{3}-0,001826^{*} h$ \\
\hline \multirow{3}{*}{ deblovnice } & Kušar, 2007 & $\begin{array}{l}v=-0,252056+0,00026424 \cdot d^{2} \cdot h-0,00000930116 \cdot d^{2} \cdot h \cdot(\ln (d))^{2}-0,000524272 \cdot d^{2} \\
-0,00484587 \cdot d \cdot h+0,0451495 \cdot h+0,0182652 \cdot d\end{array}$ \\
\hline & Puhek, 2003 & $\begin{array}{l}V=-0,2395044^{*} d^{*} h+0,0068976337^{*} d^{*} h^{2}-0,0000037308357^{*} d^{*} h^{3}+0,05938042^{*} d^{2 *} h \\
-0,00030222736^{*} d^{2 *} h^{2}-0,000431094^{*} d^{3 *} h+0,0000000064316383^{*} d^{3 *} h^{3} \\
+0,000000090518929^{*} d^{4 *} h^{2}-0,0000000000090550376^{*} d^{5 *} h^{3}\end{array}$ \\
\hline & Čokl, 1962 & $v=d^{1,73882 *} h^{1,239864 *} 0,042949192$ \\
\hline \multirow{2}{*}{ tarife } & Kušar, 2007 & $v=-0,201087+0,00332987 \cdot d+0,00120357 \cdot d^{2}$ \\
\hline & Čokl, 1956 & $v=2,303 / 1800^{*} d^{*}(d-5) \mathrm{E} 7 / 8$ \\
\hline
\end{tabular}




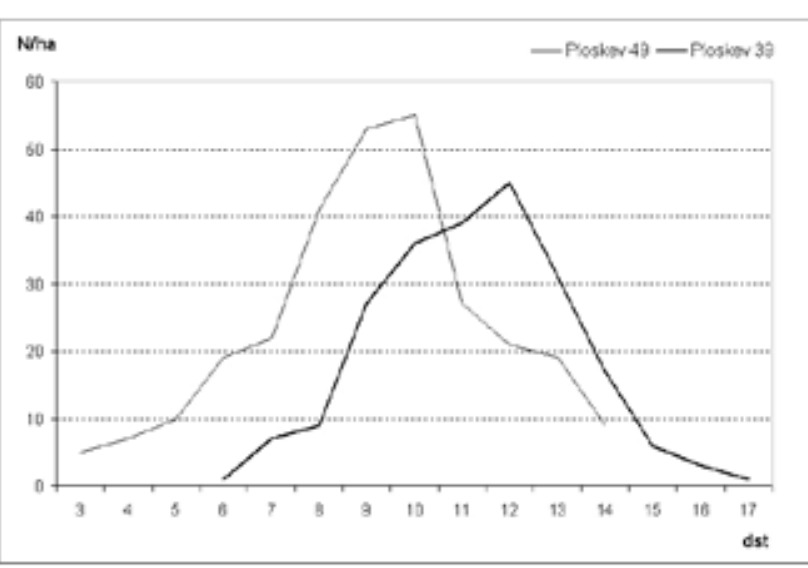

Slika 1: Frekvenčni porazdelitvi dreves smreke in njihovi višinski krivulji (logaritemska funkcija) na hektarskih raziskovalnih ploskvah na Pokljuki leta 2009

višinskih krivulj, za katere smo uporabili logaritemsko krivuljo, je mogoče oceniti, da so ob enakih povprečnih premerih smreke na ploskvi 39 višje od smrek na ploskvi 49. V 10. debelinski stopnji je razlika v povprečnih višinah večja od $2,5 \mathrm{~m}$, kar bi ob presoji o tarifnih razredih že pomenilo razliko med dvema sosednjima tarifnima razredoma in 5-odstotno razliko v volumnih dreves. Sestoja na raziskovalnih ploskvah se razlikujeta tudi po povprečnih premerih, deležu dreves v prvem debelinskem razredu in sestojni temeljnici, zato je mogoče pričakovati razlike tudi v drugih dejavnikih, ki vplivajo na ocene njunih lesnih zalog. Na podlagi troparametrske volumenske funkcije (Kušar, 2007) smo za vsako smreko izračunali volumen in ga $\mathrm{v}$ primerjavi $\mathrm{z}$ drugimi volumenskimi funkcijami privzeli kot referenčno vrednost (preglednica 1). Tarife E7/8 so bile izbrane kot izhodišče za primerjavo. Določene so bile na podlagi vseh izmerjenih višin na raziskovalnih ploskvah (slika 1).

\section{REZULTATI}

\section{RESULTS}

Kot referenčne volumne dreves $\left(v_{n}\right)$ smo uporabili volumne dreves, izračunane po Newtonovem obrazcu za sekcijske meritve. Za primerjavo med volumenskimi funkcijami smo z vsako funkcijo izračunali volumne dreves, razliko od ocene pravega volumna drevesa $\left(v_{n}\right)$

Preglednica 2: Povprečne vrednosti premerov smreke in sestojne gostote na dveh hektarskih raziskovalnih ploskvah na Pokljuki leta $2009 \mathrm{~d}_{\mathrm{a}}$ - aritmetično srednji premer, $\mathrm{d}_{\mathrm{g}}-$ srednjetemeljnični premer, N - število dreves, G - sestojna temeljnica, V - lesna zaloga)

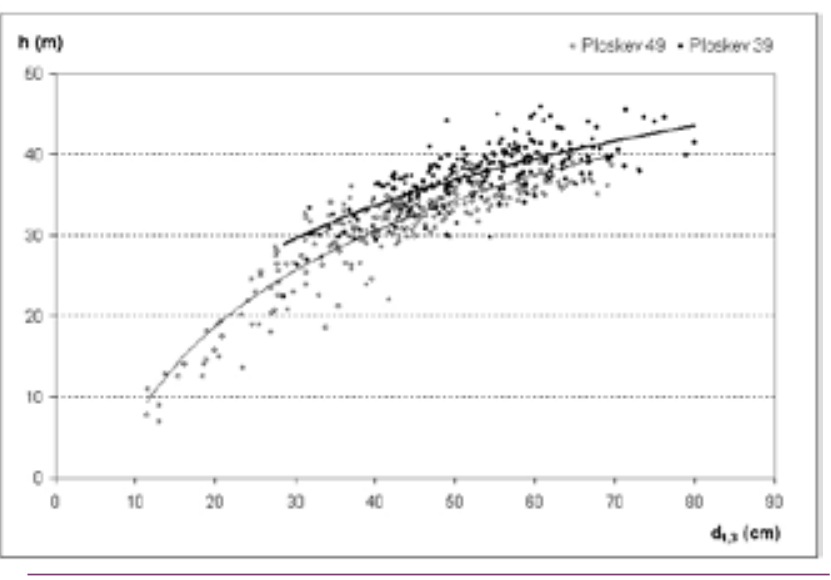

Fig. 1: Frequency distribution of spruce trees and their stand height curves (logarithmic function) estimated at two research plots on the Pokljuka plateau in 2009

ter povprečno napako odstopanj volumnov posameznih dreves (AR - average residual) in standardnim odklonom odstopanj (SR - standard deviation of the residuals) v odstotkih od povprečne referenčne vrednosti (Kaufmann, 2001; Lanz, 2004). Primerjavo med volumenskimi funkcijami smo naredili za vzorčna drevesa $\mathrm{v}$ drogovnjaku in debeljaku ter za vse smreke $\mathrm{v}$ vzorcu (preglednica 3).

Švicarske trovhodne volumenske funkcije (Hoffmann, 1984, cit. po Kaufmann, 2001) dajo v primerjavi z referenčnimi vrednostmi v povprečju za -2,0 \% (SR je 5,9 \%) premajhne vrednosti. Povprečna odstopanja so manjša pri drogovnjaku $(-1,2 \%)$ kot pri debeljaku (-2,3\%). Pred naslednjo primerjavo je treba opozoriti, da nemške dvovhodne deblovnice (Puhek, 2003) in prilagojene tarife (Čokl, 1956; 1957; 1959; 1980; Kotar, 2003) v volumnu ne zajemajo panja. Volumen panja pri analiziranih 88 drevesih predstavlja od 3,0 do 3,7 \%, v povprečju pa 3,2 \% celotnega volumna debeljadi. Nemške dvovhodne deblovnice (Puhek, 2003) dajo v primerjavi z referenčnimi vrednostmi v povprečju za -1,3 \% (SR je 12,6 \%) premajhne vrednosti. Razlike so manjše pri drogovnjaku $(0,4 \%)$ kot pri debeljaku $(-2,1 \%)$. Čoklove dvovhodne deblovnice (Čokl, 1962) dajo v primerjavi z referenčnimi vrednostmi v povprečju za 3,2 \% (SR je 14,8 \%) previsoke vrednosti. Razlike so manjše pri drogovnjaku $(2,0 \%)$

Table 2: Average diameters of spruce and stand densities at two research plots on the Pokljuka plateau in 2009 (d a - arithmeticmean diameter, $\mathrm{d}_{\mathrm{g}}$-quadraticmeandiameter, $\mathrm{N}$-number of trees, G - stand basal area, V - growing stock)

\begin{tabular}{|c|c|c|c|c|c|}
\hline Ploskev & $d_{a}(\mathbf{c m})$ & $d_{q}(\mathbf{c m})$ & $N\left(\mathbf{h a}^{-1}\right)$ & $G\left(\mathrm{~m}^{2} / \mathbf{h a}\right)$ & $V\left(\mathrm{~m}^{3} / \mathbf{h a}\right)$ \\
\hline 39 & 53,8 & 54,7 & 223 & 52,5 & 801,2 \\
\hline 49 & 43,4 & 45,1 & 289 & 46,1 & 655,7 \\
\hline
\end{tabular}


Preglednica 3: Primerjava zanesljivosti funkcij za drevesa sekcijskih meritev Pokljuka, l. 2004, (N - število dreves, V - povprečen volumen dreves, AR - povprečne razlike, SR standardni odklon odstopanj)
Table 3: Estimation of the reliability of volume functions and equations for reference trees on the Pokljuka plateau in 2004 $(\mathrm{N}$ - number of trees, $\mathrm{V}$ - average volume of trees, AR - average residuals, SR - standard deviation of the residuals in percentage of the mean volume)

\begin{tabular}{|c|c|c|c|c|c|c|c|c|c|c|}
\hline \multirow{2}{*}{$\begin{array}{l}\text { Vrsta volumenske } \\
\text { funkcije }\end{array}$} & \multirow[t]{2}{*}{ Oznaka } & \multicolumn{3}{|c|}{ 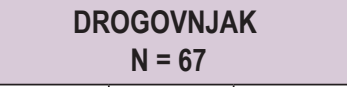 } & \multicolumn{3}{|c|}{$\begin{array}{l}\text { DEBELJAK } \\
\qquad \mathrm{N}=21\end{array}$} & \multicolumn{3}{|c|}{$\begin{array}{l}\text { SKUPAJ } \\
\mathrm{N}=88\end{array}$} \\
\hline & & $V\left(m^{3}\right)$ & $\operatorname{AR}(\%)$ & SR $(\%)$ & $\mathrm{V}\left(\mathrm{m}^{3}\right)$ & $\operatorname{AR}(\%)$ & SR $(\%)$ & $\mathrm{V}\left(\mathrm{m}^{3}\right)$ & $\operatorname{AR}(\%)$ & SR $(\%)$ \\
\hline sekcijske & Kusar, 2007 & 0,506 & - & - & 2,746 & - & - & 1,193 & - & - \\
\hline \multirow[t]{2}{*}{ trovhodne vol. funkcije } & $\begin{array}{l}\text { Hoffmann, 1984, } \\
\text { cit. po Kaufmann, } 2001\end{array}$ & 0,500 & $-1,2$ & 6,6 & 2,682 & $-2,3$ & 4,3 & 1,170 & $-2,0$ & 5,9 \\
\hline & Kusar, 2007 & 0,510 & 0,8 & 7,4 & 2,736 & $-0,3$ & 3,1 & 1,193 & $0,0^{*}$ & 4,7 \\
\hline \multirow{3}{*}{ deblovnice } & Kušar, 2007 & 0,505 & $-0,3$ & 10,7 & 2,749 & 0,1 & 8,6 & 1,193 & $0,0^{*}$ & 11,4 \\
\hline & Puhek, 2003 & 0,508 & 0,4 & 11,1 & 2,689 & $-2,1$ & 9,5 & 1,177 & $-1,3$ & 12,6 \\
\hline & Čokl, 1962 & 0,516 & 2,0 & 11,0 & 2,848 & 3,7 & 11,3 & 1,232 & 3,2 & 14,8 \\
\hline \multirow{2}{*}{ tarife } & Kušar, 2007 & 0,513 & 1,3 & 16,5 & 2,731 & $-0,5$ & 11,4 & 1,193 & $0,0^{*}$ & 15,4 \\
\hline & Čokl, 1956 & 0,536 & 5,9 & 17,4 & 2,648 & $-3,6$ & 11,9 & 1,184 & $-0,8$ & 16,2 \\
\hline
\end{tabular}

*razlika $0,000 \mathrm{~m}^{3}$ oz $0,0 \%$ je seveda posledica testiranja funkcij na istih drevesih, iz katerih so bile funkcije izdelane

kot pri debeljaku $(3,7 \%)$. Za praktično uporabo so torej enako zanesljive nemške dvovhodne deblovnice (Puhek, 2003) in tudi Čoklove (1962). Pri izbiranju tarif smo primerjali skladnost $\mathrm{z}$ referenčnimi volumni in izbrali najprimernejši tarifni niz iz prilagojenih enotnih francoskih tarif za enodobne sestoje (Čokl, 1957). $S$ tarifnim nizom E7/8 smo v primerjavi z referenčnimi vrednostmi v povprečju ocenili za -0,8 \% (SR je 16,2 $\%)$ premajhne vrednosti volumnov. Pri debeljaku dobimo s tarifo E7/8 za -3,6 \% prenizke vrednosti, pri drogovnjaku pa za 5,9\% previsoke. Če pri debeljaku vzamemo za pol tarifnega razreda višjo tarifo (E8), dobimo manjšo napako (1,2 \%). Prav tako dobimo manjšo napako ocene $(0,6 \%)$, če za drogovnjak vzamemo za pol tarifnega razreda nižjo tarifo (E7). To potrjuje preskok tarif v enodobnih sestojih s starostjo, kar pomeni, da tarife $\mathrm{z}$ razvojem sestoja naraščajo in jih je treba ustrezno prilagajati. Za praktično uporabo so

Preglednica 4: Povprečne razlike (AR) in odstopanja (SR) za modele volumenskih funkcij, deblovnic in tarif v primerjavi z referenčno volumensko funkcijo (Kušar, 2007) prilagojene enotne francoske tarife dovolj zanesljive, če so ustrezno izbrane. Odstopanja ocen volumnov posameznih dreves od referenčnih vrednosti pa so pri tarifah lahko večja (17 \%).

Za drevesa na obeh raziskovalnih ploskvah smo izračunali povprečne razlike (AR) in odstopanja (SR) za modele volumenskih funkcij, deblovnic in tarif, ki smo jih primerjali z izračunanimi volumni. Za izračun referenčnih vrednosti smo privzeli trovhodno volumensko funkcijo (Kušar, 2007), ocenjeno iz sekcijskih meritev smreke na Pokljuki (preglednica 4).

$\mathrm{Na}$ obeh raziskovalnih ploskvah smo z lastno volumensko funkcijo (Kušar, 2007) določili večje volumne dreves kot s švicarsko volumensko funkcijo (Hoffmann, 1984, cit. po Kaufmann, 2001). S prirejenimi nemškimi deblovnicami (Puhek, 2003) bi smrekam določili previsoke volumne, čeprav podajajo vrednosti brez volumna panjev. Ker volumne iz teh deblovnic uporabljamo

Table 4: Average residuals (AR) and standard deviations of the residuals (SR) in percentage of the mean volume for the volume functions, two-entry volume tables and tariff functions in comparison with reference volume function (Kušar, 2007)

\begin{tabular}{|c|c|c|c|c|c|c|}
\hline & & \multicolumn{2}{|c|}{ Ploskev $39(n=223)$} & \multicolumn{3}{|c|}{ Ploskev $49(n=289)$} \\
\hline & & $A R(\%)$ & SR (\%) & $\operatorname{AR}(\%)$ & SR (\%) & panj/stump \\
\hline $\begin{array}{l}\text { trovhodne vol. } \\
\text { funkcije }\end{array}$ & $\begin{array}{l}\text { Hoffmann, 1984, cit. } \\
\text { po Kaufmann, } 2001\end{array}$ & $-1,77$ & 2,47 & $-5,02$ & 5,74 & + \\
\hline \multirow{2}{*}{ deblovnice } & Kušar, 2007 & 6,25 & 9,91 & 3,45 & 10,93 & + \\
\hline & Puhek, 2003 & 5,38 & 10,44 & 1,96 & 10,04 & - \\
\hline \multirow{3}{*}{ tarife } & Kušar, 2007 & $-0,57$ & 12,42 & 4,64 & 13,91 & + \\
\hline & Čokl, 1957 (E 7/8) & $-3,22$ & 12,85 & 1,70 & 13,26 & - \\
\hline & Čokl, 1957 (E 8) & 1,61 & 12,93 & 6,78 & 14,95 & - \\
\hline
\end{tabular}




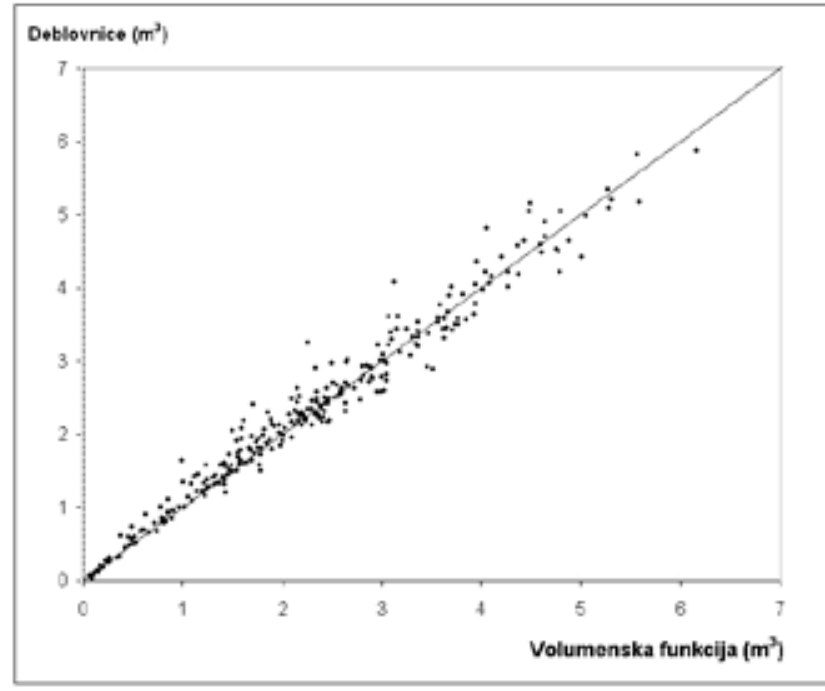

Slika 2: Primerjava volumnov debeljadi smreke na ploskvi 49 , izračunanih iz volumenskih funkcij in prirejenih deblovnic (a) ter prirejenih tarif za enomerne sestoje (E 7/8) na Pokljuki

tudi pri določanju prirejenih tarif na Slovenskem (Čokl, $1957 ; 1959)$, je s takim postopkom določen tarifni razred z vsaj za $5 \%$ previsokimi volumni dreves. 0 tem sklepamo na podlagi previsokih volumnov v deblovnicah, ki enako kot tarife ocenjujejo volumne debeljadi brez panja. Premalo zanesljive so tudi deblovnice in tarife, ki so bile izpeljane iz sekcijskih meritev smreke na Pokljuki. Za lokalne tarife smo na ploskvi 39 določili najmanjša odstopanja od referenčnih volumnov,

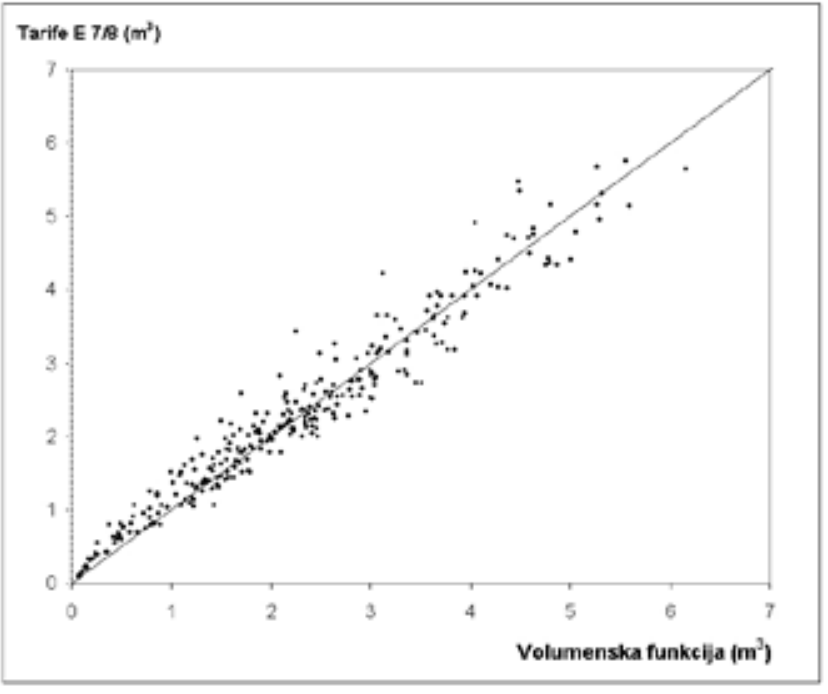

Fig. 2: Comparison of computed spruce stem volumes on research plot 49 based on volume functions and adapted two entry volume tables (a) and with Slovene tariff function (E 7/8) for uniform stands on the Pokljuka plateau

vendar bi z njimi na ploskvi 49 določili previsoke vrednosti, ker ne upoštevajo razlik v višinah smrek na obeh ploskvah. Te razlike ponazarjata tarifna razreda prirejenih tarif za enodobne oziroma enomerne sestoje (Čokl, 1957; 1959), ki so bile zasnovane tako, da se njihovi volumni pri prehodu k višjemu sosednjemu nizu povečajo za $5 \%$. Na ploskvi 49, v debeljaku z mlajšimi smrekami, prirejene deblovnice in tarife določajo manjše razlike v volumnih, vendar bi ob dodatnem

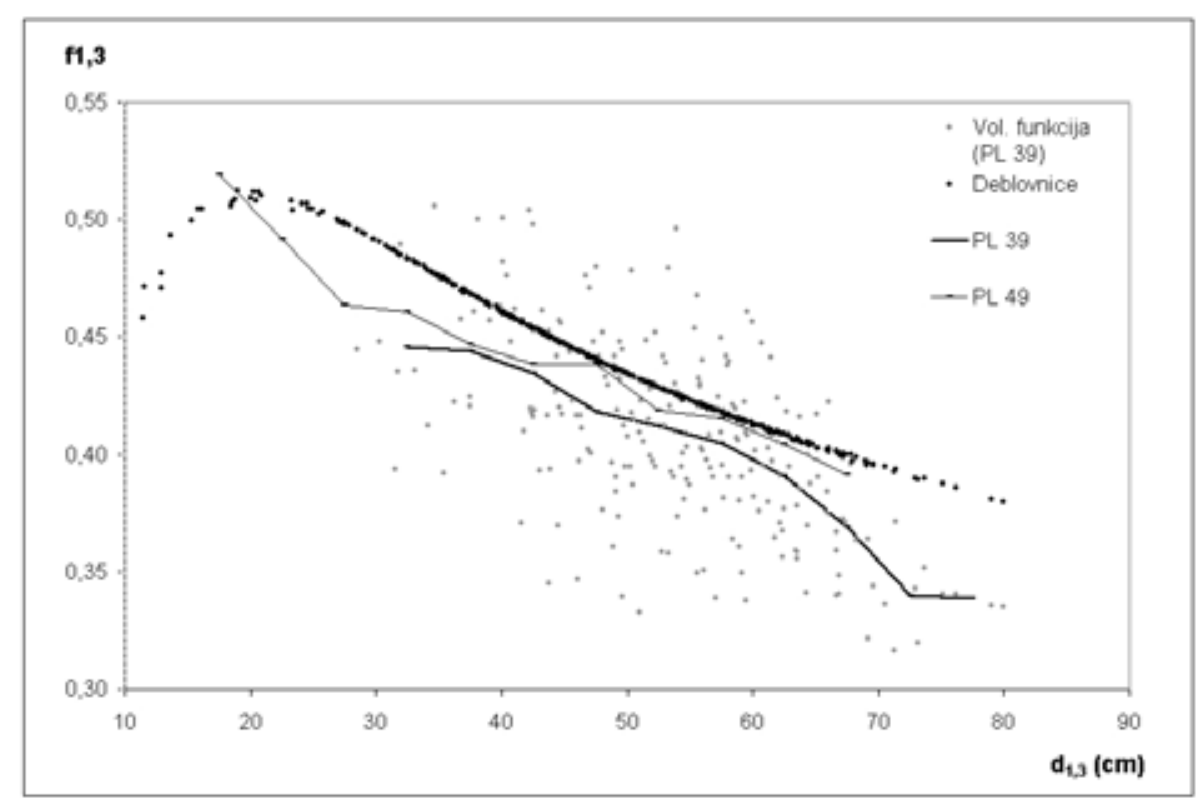

Slika 3: Primerjava nepravih oblikovnih števil $\left(f_{1,3}\right)$, izračunanih iz volumenske funkcije za smreko (Kušar, 2007) in prirejenih dvovhodnih deblovnic (Puhek, 2003). Za drevesa na obeh raziskovalnih ploskvah so bila izračunana povprečna oblikovna števila po debelinskih stopnjah in prikazana s povezanimi daljicami (PL 39, PL 49).
Fig. 3: Comparison of breast height form factors of spruce $\left(f_{1,3}\right)$ for computed volumes based on volume function (Kušar, 2007) and adapted two-entry volume tables (Puhek, 2003), shown as averages for diameter classes on two research plots 
upoštevanju volumna panja povprečna odstopanja dosegla do $5 \%$ višje volumne od referenčne vrednosti volumenske funkcije (slika 2, preglednica 4).

Na sliki 2 je za prirejene tarife prikazano precenjevanje volumnov smrek vse do vrednosti $2 \mathrm{~m}^{3}$, to je pri 9. debelinski stopnji, kar je nižje od vrednosti srednjetemeljničnega premera na tej raziskovalni ploskvi. Precenjevanje volumnov tanjših dreves izvira iz prirejenih dvovhodnih deblovnic, iz katerih smo izračunali neprava oblikovna števila in jih primerjali s tistimi, ki smo jih izračunali iz volumenskih funkcij. Povprečne vrednosti nepravih oblikovnih števil so na obeh raziskovalnih ploskvah nižje od vrednosti teh števil za dvovhodne deblovnice. Nizke vrednosti nepravih oblikovnih števil za drevesa v 14. in višjih debelinskih stopnjah na raziskovalni ploskvi 39 ponazarjajo visoke padce premera, ki smo jih ocenili na dolžinah debla med prsnim premerom $\left(d_{1,3}\right)$ in premerom na sedmih metrih $\left(d_{7}\right)$, ter manjše vrednosti oblikovnih količnikov $d_{7} / d_{1,3}$. Za smreke, debelejše od $65 \mathrm{~cm}$, smo ocenili, da je padec premera med $2,7 \mathrm{~cm} / \mathrm{m}$ v 14 . debelinski stopnji do 3,4 $\mathrm{cm} / \mathrm{m}$ v 16. debelinski stopnji. Taka ocena padca premera izvira iz oblikovnih količnikov $d_{7} / d_{1,3}$, ocenjenih med vrednostmi 0,77 in 0,75 . V debelinskih stopnjah, manjših od 12., so padci premera manjši od $2 \mathrm{~cm} / \mathrm{m}$, za oblikovne količnike $d_{7} / d_{1,3}$ pa smo ocenili vrednosti med 0,79 in 0,80 (slika 3 ).

\section{RAZPRAVA}

\section{DISCUSSION}

S primerjavo trovhodnih volumenskih funkcij, deblovnic in tarif za smreko na modelnem območju smo prikazali niz neraziskanih problemov pri določanju volumnov dreves in lesne zaloge gozdnih sestojev na Slovenskem. Lesno zalogo sestojev ugotavljamo najpogosteje z enoparametrskimi volumenskimi funkcijami - tarifami. Slovenske prirejene tarife za določanje volumna dreves na podlagi prsnega premera izvirajo iz skupine najzgodnejših enačb za ocenjevanje volumna dreves, kajti izvirne francoske tarife, opisane v klasičnih učbenikih o izmeri gozdov (Pardé in Bouchon, 1988, Van Laar in Akça, 2010), je Algan predstavil že leta 1901, Schaeffer pa delo dopolnil leta 1949. Ker ni pričakovati, da bi jih na Slovenskem v celoti nadomestili z novejšimi volumenskimi funkcijami, smo v predhodnih raziskovanjih preverili njihovo zanesljivost pri določanju volumna najpomembnejših drevesnih vrst na Slovenskem (Kušar, 2007) in predlagali postopke za njihovo določanje pri operativnem delu v gozdni inventuri (Kušar in Hočevar, 2009). Za prirejene tarife, zasnovane za uporabo na sestojni ravni, so bili sprva postopki za njihovo določanje povezani s polno izmero gozdnih sestojev. Z določanjem debelinske stopnje, kjer se lesna zaloga gozdnega sestoja razpolavlja, je bilo predvideno, da bodo zanesljivo ocenjevale volumne dreves $\mathrm{v}$ debelinskih stopnjah $\mathrm{s}$ pričakovanim povprečnim volumenskim drevesom. Z vzorčnim izbiranjem dreves se je težavnost določanja tarif še povečala, kajti ob ocenjevanju višinskih krivulj za posamezne drevesne vrste ni bilo na voljo domačih deblovnic, s katerimi bi ocenjevali volumne dreves in sklepali o primernem tarifnem razredu za oceno lesne zaloge. Že ob začetkih uporabe prirejenih tarif so opozorili na neprimernost prirejenih nemških deblovnic, prek katerih na podlagi volumnov dreves sklepamo o izbiri tarifnih nizov (Čokl, 1962). Ker vsebinski razlogi za neskladnost s prirejenimi nemškimi deblovnicami niso bili raziskani, smo posebej primerjali neprava oblikovna števila za smreko na raziskovalnih ploskvah (slika 3) in ocenili podobna odstopanja, kot smo jih odkrili pri oblikovnih številih jelke (Hladnik in Kobal, 2012).

Največje razlike $\mathrm{v}$ oblikovnih številih smo odkrili pri drevesih, debelejših od $60 \mathrm{~cm}$. Za starejša drevesa je značilno, da nastopi kulminacija višinske rasti veliko prej kot pri debelinskem prirastku, hkrati pa imajo v povprečju nižje razmerje oblikovnih količnikov $d_{7} /$ $d_{1,3}$ kot druga drevesa (Kaufmann, 2001). Ker doslej v gozdnih inventurah na Slovenskem nismo uporabljali finske premerke za merjenje dodatnih premerov dreves na 5 ali 7 metrih višine, nismo ocenjevali takih oblikovnih količnikov in njihovega pomena pri spreminjanju oblike drevesnega debla. Za ponazoritev teh sprememb smo v prispevku izračunali padce premera med prsnim premerom in dodatnim premerom na 7 metrih, ki so bili v povprečju podobni vrednostim za stare jelke v Leskovi dolini (Hladnik in Kobal, 2012). Doslej smo pri spremljanju razvoja enodobnih ali enomernih gozdnih sestojev in pri določanju tarifnih nizov upoštevali njihovo povečevanje skladno s preskokom sestojnih višinskih krivulj, kar smo prikazali tudi za sestoje na raziskovalnih ploskvah na Pokljuki (Hladnik in Skvarča, 2009). Za natančnejše določanje volumnov dreves je treba nadaljevati $\mathrm{z}$ razvojem volumenskih funkcij, kajti za smreko (Kušar, 2007) in jelko (Hladnik in Kobal, 2012) smo na modelnih območjih Pokljuke, Ravnika in Leskove doline pokazali prevelika odstopanja od švicarskih volumenskih funkcij (Hoffmann, 1984, cit. po Kaufmann, 2001).

Za trovhodne volumenske funkcije in z njimi povezano merjenje treh znakov drevesa je pomembno, da pridobimo poleg zanesljivejše ocene volumnov dreves tudi možnosti za ocenjevanje dodatnih parametrov 
drevesa, ki omogočajo na primer tudi prvo sklepanje o kakovosti in sortimentni sestavi debla. Na vzorčnih ploskvah nacionalnih gozdnih inventur drevesa $\mathrm{z}$ merjenimi tremi znaki predstavljajo podvzorec za kalibracijo tarif, s katerimi so izračunani volumni drugih dreves, ki so jim izmerili le prsni premer (Lanz in sod., 2007). Podoben postopek smo izpeljali na dveh hektarskih raziskovalnih ploskvah. 0 razlikah pri uporabi različnih volumenskih funkcij, deblovnic in tarif nismo sklepali le na podlagi majhnega vzorca sekcijsko izmerjenih dreves, temveč smo v primerjavi volumnov dreves na raziskovalnih ploskvah privzeli vrednosti volumenskih funkcij kot referenčne vrednosti. Na podlagi takih referenčnih vrednosti je mogoče zanesljiveje določiti tarifni razred (preglednica 4), hkrati pa lahko sklepamo, da so slovenske prirejene tarife (Čokl, 1957) kljub svoji preprosti zasnovi primerne za določanje lesne zaloge gozdnih sestojev.

Za oceno natančnosti volumenskih funkcij pri napovedovanju volumnov posameznih dreves je treba zagotoviti večji vzorec dreves. Do takrat lahko ostanemo ob ocenah, da je povprečna razlika volumnov dreves enakih premerov in višin, ki nastane zaradi različne oblike debla oz. vzrasti, $5 \%$, za posamezna drevesa tudi do $15 \%$ (Čokl, 1957). Zanesljivost nemških dvovhodnih deblovnic je bila ocenjena na 5-7 \%, za posamezna drevesa do 15 \% (Čokl, 1980; Emrović, 1953). Kljub majhnemu vzorcu sekcijsko izmerjenih smrek lahko o pomenu trovhodnih volumenskih funkcij sklepamo na podlagi standardne napake ocene povprečne vrednosti volumna (preglednici 1 in 3), ki je bila pri trovhodnih volumenskih funkcijah trikrat manjša od standardne napake pri lokalno zasnovanih tarifah in dvakrat manjša od napake pri lokalnih deblovnicah.

\section{POVZETEK}

Namen raziskave je bil oceniti zanesljivost različnih volumenskih funkcij za smreko in preveriti, kakšna je zanesljivost pri določanju tarif $\mathrm{v}$ enomernih gozdnih sestojih. Volumenske funkcije, ki jih uporabljamo za izračune volumna dreves in posledično tudi lesne zaloge, so različno točne in natančne. Za volumenske funkcije v gozdarski praksi je poleg njihove zanesljivosti pomembna tudi enostavnost za uporabo. Večvhodne volumenske funkcije so bolj zanesljive, zahtevajo pa več meritev, dražje inštrumente ter bolj šolane in izkušene merilce in so zato stroškovno ter časovno manj primerne. V praksi lahko najbolj enostavno in natančno izmerimo prsni premer $(D)$, težje in manj natančno višino drevesa $(H)$, še težje pa izmerimo obliko drevesa oz. zgornji premer $(D Z)$. Zato so za praktično uporabo najenostavnejše tarife, nato deblovnice in nazadnje trovhodne volumenske funkcije.

Na Pokljuki smo izmerili sekcije na 88 podrtih smrekah. Na podlagi ocen pravih volumnov dreves $\left(v_{n}\right)$, izračunanih s sekcijskimi meritvami po Newtonovem obrazcu, smo s pomočjo multiple (za trovhodne volumenske funkcije, deblovnice) in polinomske regresijske analize (tarife) izdelali regionalne trovhodne volumenske funkcije, deblovnice in tarife. Ugotovili smo, da je standardna napaka ocene povprečne vrednosti volumna drevesa, izračunanega z regionalnimi volumenskimi funkcijami, najmanjša pri trovhodnih volumenskih funkcijah (5,0\%), nato pri deblovnicah $(11,7 \%)$ in največja pri tarifah $(15,1 \%)$. Delež variabilnosti odvisne spremenljivke $v_{n}$, ki ga pojasnimo z regresijo med odvisno spremenljivko $v_{n}$ in neodvisnimi spremenljivkami $\left(d, h\right.$ in $\left.d_{7}\right)$, je zelo velik. Že vključitev samo ene spremenljivke $(d) \mathrm{v}$ model pojasni velik del variabilnosti $\left(\mathrm{R}^{2}\right.$ je 0,9766$)$. Pri deblovnicah se $\mathrm{z}$ vključitvijo še ene spremenljivke $(h)$ pojasnjeni del variance še poveča $\left(R^{2}\right.$ je 0,9865$)$. Pri trovhodnih volumenskih funkcijah pa je z vključitvijo še ene dodatne spremenljivke $\left(d_{7}\right)$ delež pojasnjene variabilnosti še večji $\left(R^{2}\right.$ je 0,9976).

Na vzorcu 88 dreves sekcijskih meritev smo nato primerjali zanesljivost različnih volumenskih funkcij. Švicarske trovhodne volumenske funkcije (Hoffmann, 1984, cit. po Kaufmann, 2001) dajo v primerjavi z referenčnimi vrednostmi v povprečju za -2,0 \% (SR je 5,9 $\%)$ premajhne vrednosti. Nemške dvovhodne deblovnice (Puhek, 2003) dajo v povprečju za -1,3 \% (SR je $12,6 \%$ premajhne vrednosti, Čoklove (1962) dvovhodne deblovnice pa za 3,2 \% (SR je 14,8 \%) previsoke vrednosti. Prilagojene enotne francoske tarife za enodobne sestoje (Čokl,1957) dajo za tarifo E7/8 v povprečju za -0,8 \% (SR je 16,2 \%) premajhne vrednosti. Pri debeljaku dobimo s tarifo E7/8 za -3,6 \% prenizke vrednosti, pri drogovnjaku pa za 5,9 \% previsoke. Če pri debeljaku vzamemo za pol tarifnega razreda višjo tarifo (E8), dobimo manjšo napako (1,2 \%). Prav tako dobimo manjšo napako ocene $(0,6 \%)$, če za drogovnjak vzamemo za pol tarifnega razreda nižjo tarifo (E7). To potrjuje preskok tarif v enodobnih sestojih s starostjo, kar pomeni, da tarife z razvojem (enodobnega) sestoja naraščajo in jih je treba ustrezno prilagoditi. Za praktično uporabo so prilagojene enotne francoske tarife (Čokl, 1957) dovolj zanesljive, če so ustrezno izbrane. Odstopanja ocen volumnov posameznih dreves od referenčnih vrednosti pa so lahko večja (17 \%).

Nato smo izdelane regionalne in tuje trovhodne volumenske funkcije, deblovnice in tarife preizkusili še 
na dveh hektarskih raziskovalnih ploskvah (št. 39 in 49) na Pokljuki. Sestoja na raziskovalnih ploskvah se razlikujeta po višinskih krivuljah, po povprečnih premerih, deležu dreves $v$ prvem debelinskem razredu in sestojni temeljnici, zato je mogoče pričakovati razlike tudi $\mathrm{v}$ drugih dejavnikih, ki vplivajo na ocene njunih lesnih zalog. Na obeh raziskovalnih ploskvah smo z lastno volumensko funkcijo - regionalna trovhodna volumenska funkcija - določili večje volumne dreves kot s švicarsko volumensko funkcijo (Hoffmann, 1984, cit. po Kaufmann, 2001). S prirejenimi nemškimi deblovnicami (Puhek, 2003) bi smrekam določili previsoke volumne, čeprav podajajo vrednosti brez volumna panjev. Ker volumne iz teh deblovnic uporabljamo tudi pri določanju prirejenih tarif na Slovenskem (Čokl, 1957; 1959), je s takim postopkom določen tarifni razred z vsaj za $5 \%$ previsokimi volumni dreves. Premalo zanesljive so tudi naše regionalne deblovnice in lokalne tarife, ki so bile izpeljane iz sekcijskih meritev smreke na Pokljuki. Za lokalne tarife smo na ploskvi 39 določili najmanjša odstopanja od referenčnih volumnov, vendar bi z njimi na ploskvi 49 določili previsoke vrednosti, ker ne upoštevajo razlik $\mathrm{v}$ višinah smrek na obeh ploskvah. Te razlike ponazarjata tarifna razreda prirejenih tarif za enodobne oziroma enomerne sestoje (Čokl, 1957; 1959), ki so bile zasnovane tako, da se njihovi volumni pri prehodu k višjemu sosednjemu nizu povečajo za $5 \%$.

Ugotovili smo tudi, da precenjevanje volumnov tanjših dreves izvira iz prirejenih dvovhodnih deblovnic, iz katerih smo izračunali neprava oblikovna števila in jih primerjali s tistimi, ki smo jih izračunali iz volumenskih funkcij. Povprečne vrednosti nepravih oblikovnih števil so na obeh raziskovalnih ploskvah nižje od vrednosti teh števil za dvovhodne deblovnice.

\section{SUMMARY}

The aim of the research was to estimate the reliability of various volume functions for the spruce and to determine the reliability of tariff measurements in even-aged forest stands. Volume functions used when calculating tree volumes and, consequently, growing stock, differ in accuracy and precision. In the applied forestry, volume functions should not be only accurate, but also simple to use. Although multiple-entry volume functions have a higher reliability, they require more measurements, more expensive instruments and more highly educated and experienced measurers, which makes them less suitable as regards time and expenses. In praxis, it is the easiest and most accurate to measure the diameter at breast height $(D)$, more difficult and less accurate to measure the tree height $(H)$, and even more difficult to measure the taper of the tree or the upper diameter $(D Z)$. Consequently, the easiest to use are tariffs, then volume tables and lastly three-entry volume functions.

On the plateau of Pokljuka, sections were measured on 88 felled spruce trees. Based on the estimations of true tree volumes $\left(v_{n}\right)$, obtained with section measurements according to Newton's equation, we used multiple (for three-entry volume functions and volume tables) and polynomial regression analysis (for tariffs) in order to formulate regional three-entry volume functions, volume tables and tariffs. It was determined that the standard error of the average value of tree volume calculated by means of regional volume functions was the smallest for three-entry volume functions (5.0\%), then for volume tables $(11.7 \%)$ and the largest for tariffs (15.1\%). The variability share of the dependent variable $v_{n}$, which can be explained with the regression between the dependent variable $v_{n}$ and the independent variables $\left(d, h\right.$ and $\left.d_{7}\right)$, is very high. Even the inclusion of only one variable $(d)$ in the model can explain a high share of variability $\left(R^{2}\right.$ $=0.9766)$. With volumes including another variable (h), the explained share of variability grows higher $\left(\mathrm{R}^{2}\right.$ $=0.9865)$, whereas in the case of three-entry volume functions including yet another variable $\left(d_{7}\right)$ the share grows even further $\left(\mathrm{R}^{2}=0.9976\right)$.

Using a sample of 88 trees from the section measurement, we compared the reliability of various volume functions. On average, the results of the Swiss three-entry volume functions (Hoffmann, 1984, cit. after Kaufmann, 2001) are in comparison with the reference values $-2.0 \%(\mathrm{SR}=5.9 \%)$ too low. The values of the adapted German two-entry volume tables (Puhek, 2003) are on average $-1.3 \%(\mathrm{SR}=12.6 \%)$ too low, while Čokl's (1962) two-entry volume tables are on average $3.2 \%(\mathrm{SR}=14.8 \%)$ too high. The adapted uniform French tariffs for even-aged stands (Čokl, 1957) result for the tariff $E 7 / 8$ in values being on average $-0.8 \%$ (SR is $16.2 \%$ ) too low. In the case of large timber, the values gained with the E7/8 tariff are $-3.6 \%$ too low, whereas for pole stand, they are $5.9 \%$ too high. Using a half a tariff class higher tariff (E8) for large timber, the error is smaller (1.2\%). Similarly, the estimation error is smaller $(0.6 \%)$ for pole stand if applying by a half a tariff class lower tariff (E7). This can be confirmed by the tariffs being skipped in evenaged stands as their age advances, meaning that the tariffs grow simultaneously with the development of an (even-aged) stand and must therefore be appropriately adapted. For practical usage, the adapted uniform French tariffs (Čokl, 1957) are reliable enough, if well- 
chosen. However, the differences between volume estimations of individual trees and the reference values can be higher (17\%).

Consequently, the developed regional and foreign three-entry volume functions, volume tables and tariffs were additionally tested at two research plots on the Pokljuka plateau, each measuring a hectare (Nos. 39 and 49). Since the stands on the research plots differ in height curves, average diameters, tree share in the diameter and basal area classes, differences in other factors influencing the estimation of growing stock on the plots can be expected as well. On both research plots, our own regional three-entry volume function resulted in higher tree volumes as the Swiss volume function (Hoffmann, 1984, cit. after Kaufmann, 2001). With the adapted German volume tables (Puhek, 2003), the estimated spruce volumes would be too high, even though their values exclude stump volumes. As the volumes measured in this manner are used when determining the adapted tariffs in Slovenia (Čokl, 1957; 1959), this procedure results in a tariff class of at least $5 \%$ too high tree volumes. Our regional volume tables and local tariffs derived from the section measurements of spruce on the Pokljuka are also insufficiently reliable. On plot 39 , we determined the lowest deviations from the reference volumes for the local tariffs. In the case of plot 49, however, they would result in the values being too high, since they ignore the differences in spruce heights on both plots. These differences are illustrated by the tariff classes of adapted tariffs for even-aged stands (Čokl, 1957; 1959) that were designed so that their volumes increase by $5 \%$ when reaching the next higher tariff class.

Additionally, we assessed that the overestimation of volumes of thinner trees originated from the adapted two-entry volume tables, which we used in order to calculate breast height form factors and compared them with the ones calculated from the volume functions. On both research plots, the average values of breast height form factors are lower than the values of these numbers for two-entry volume tables.

\section{ZAHVALA}

\section{ACKNOWLEDGMENT}

Del raziskav je bil opravljen v okviru doktorskega študija Gala Kušarja, ki je potekal v okviru programa Mladi raziskovalci, ki ga financira Javna agencija za raziskovalno dejavnost Republike Slovenije. Zahvala gre tudi recenzentoma za koristne pripombe.

\section{LITERATURA}

\section{REFERENCES}

Čokl M. 1956. Inventarizacija kmečkih gozdov po novih enotnih tarifah. Gozdarski vestnik, 14, 1: 1-12.

Čokl M. 1957. Prirejene Alganove in Schafferjeve tarife ter njihova raba pri inventraizaciji sestojev. Zbornik gozdarstva in lesarstva, 2: 165-195.

Čokl M. 1958. Gozdarski in lesnoindustrijski priročnik. Druga izdaja. IGLG, Strokovna in znanstvena dela, $310 \mathrm{str}$.

Čokl M. 1959. Tarife za sestoje prehodnih oblik. Gozdarski vestnik, 17: 221-228.

Čokl M. 1962. Dvovhodne deblovnice za celjski okraj. Gozdarski vestnik, 20: 257-271.

Čokl M. 1971. Raziskovalne ploskve v Blejskem gozdnogospodarskem območju. Ljubljana, IGLG, 49 str.

Čokl M. 1980. Gozdarski in lesnoindustrijski priročnik.Tablice. 5. izdaja. Ljubljana, Biotehniška fakulteta, VTOZD za gozdarstvo: 374 str.

Emrović B. 1953. 0 konstrukciji lokalnih jednoulaznih drvnogromadnih tablica (tarifa). Šumarski list, 4/5: 214-220.

Hladnik D., Skvarča A. 2009. Gozdarske raziskovalne ploskve in stalne vzorčne ploskve na območjih Natura 2000 na Slovenskem. Gozdarski vestnik 67, 1: 3-52.

Hladnik D., Kobal M. 2012. Ocenjevanje natančnosti deblovnic in volumenskih funkcij. Zbornik gozdarstva in lesarstva, 98: 3-14.

Hočevar M. 1995. Dendrometrija - gozdna inventura. Ljubljana, Biotehniška fakulteta, Oddelek za gozdarstvo: $274 \mathrm{str}$.

Husch B., Beers T.W., Kershaw J.A. 2003. Forest Mensuration. $4^{\text {th }}$ edition. New York, John Wiley \& Sons. 443 str.

Kaufmann E. 2000. Tarife für Schaftholz in Rinde und RundholzSortimente. Birmensdorf, WSL Swiss Federal Research Institute. 53 str.

Kaufmann E. 2001. Estimation of Standing Timber, Growth and Cut. V: Swiss National Forest Inventory: Methods and Models of the Second Assessment. Brassel P. (ed.), Lischke H. (ed.). Birmensdorf, WSL Swiss Federal Research Institute: 162-196.

Kotar M. 1970. Določanje vrednosti in vrednostnega prirastka sestoja. Gozdarski vestnik, 28: 200-208.

Kotar M. 2003. Gozdarski priročnik. 7. izdaja. Ljubljana, Biotehniška fakulteta Univerze v Ljubljani, Oddelek za gozdarstvo in obnovljive gozdne vire: 414 str.

Kušar G. 2007. Zanesljivost ugotavljanja volumna dreves in lesne zaloge sestojev z enoparametrskimi funkcijami in stratifikacijo: doktorska disertacija/doctoral dissertation. Ljubljana, samozaložba. $243 \mathrm{str}$.

Kušar G., Hočevar M. 2009. Izbor ustreznega tarifnega niza prilagojenih enotnih francoskih tarif za izračun lesne zaloge sestojev v sklopu kontrolne vzorčne metode. V: Planinšek Š. (ur.), Kovač M. (ur.). Kontrolna vzorčna metoda v Sloveniji - zgodovina, značilnosti in uporaba, (Studia forestalia Slovenica, 134). Ljubljana: Gozdarski inštitut Slovenije, Založba Silva Slovenica, str. 69-83.

Lanz A. 2004. A short description of Swiss NFI. Tipkopis: 6 str.

Lanz A., Di Cosmo L., Robert N., Gschwantner T. 2007. Status of European NFI Systems. Part II: Tree Definitions and Volume Functions. COST E43 on Harmonisation of National Forest Inventories in Europe. http://www.metla.fi/eu/cost/e43/members/ wg1/wg1-q2-supp-II-report.pdf (7. 12. 2012)

Pardé J., Bouchon J. 1988. Dendrometrie, ENGREF, Nancy: 328 str.

Puhek V. 2003. Regresijske enačbe za volumen dreves po dvovhodnih deblovnicah. V: Gozdarski priročnik. 7. izdaja. Kotar M. (ur.). Ljubljana. Biotehniška fakulteta Univerze v Ljubljani, Oddelek za gozdarstvo in obnovljive gozdne vire: $46-48$ str. 
Rebula E. 1995. Tablice oblikovnega števila, debeljadi in količine izdelanih sortimentov. Gozdarski vestnik 53, 10: 402-425.

Rebula E. 1996. Uporabnost prirejenih Alganovih in Schaefferjevih ter vmesnih tarif za računanje lesne mase naše jelke. Gozdarski vestnik 54, 10: 480-501

Rebula E. 2002. Izkoristek lesa pri sečnji bukovine. Zbornik gozdarstva in lesarstva, 69: 197-213.

Schmid P., Roiko-Jokela P., Mingard P., Zobeiry M. 1971. The Optimal Determination of the Volume od Standing Trees. Wien, Mitteilung der Forstlichen Bundesversuchsanstalt, 91: 33-54.

Tomppo E., Gschwantner Th., Lawrence M., McRoberts R.E. (Eds.). 2010. National Forest Inventories - Pathways for Common Reporting. Springer, Heidelberg Dordrecht London New York. p. 57-71.
Van Laar A., Akça A. 2010. Forest Mensuration. Dordrecht, Springer, 383 str.

Wagner M. 1982. Ermittlung von Einzelstamm-Volumen mit D1,3, H und oberen Stammdurchmessern. Allgemeine Forst-und JagdZeitung, 153, 4: 72-75.

Winzeler K. 1986. Volumenbestimmung durch Messungen am stehenden Baum. Zurich, Eidgenossischen Anstalt fur das forstliche Versuchswesen, 62, 1: 3-99.

Zianis D., Muukkonen P., Makipaa R., Mencuccini M. 2005. Biomass and stem volume equations for tree species in Europe. Silva Fennica Monographs 4.63 str. 